\title{
The Platelet-Lymphocyte Ratio As a Novel Predictor of Severity in Patients With Unstable Angina Pectoris: Randomized Control Double-Blind Study
}

\author{
Kararsiz Angina Pektorisli Hastalarda Ciddiyetin Yeni Bir Belirteci Olarak Trombosit Lenfosit \\ Oranı: Randomize Kontrollü Çift Kör Çalıșma
}

\author{
Mustafa Bolatkale', Ahmet Cagdas Acara ${ }^{2}$ \\ ${ }^{1}$ Department of Emergency Medicine, Alsancak State Hospital; ${ }^{2}$ Department of Emergency Medicine, Urla State Hospital, İzmir, Turkey
}

\begin{abstract}
Aim: Acute Coronary Syndrome (ACS); covers a wide spectrum of clinical conditions ranging from Non-ST and ST-Elevation Myocardial Infarction to unstable angina pectoris (UAP). UAP does not show detectable with any biomarkers in the Emergency Department (ED). Platelet-lymphocyte ratio ( $P L R$ ) has been introduced as a potential marker to determine excess thrombotic activity and inflammation in cardiac disorders. Syntax score (SXscore) is an anatomic scoring system based on coronary angiography that quantifies lesion severity and complexity and predicts poor cardiovascular outcomes, including mortality, in patients with ACS. This study aimed to investigate the predictive value of PLR compared with SXscore in patients with UAP in the ED.
\end{abstract}

Material and Method: The study group consisted of patients diagnosed with UAP who presented in ED and adult patients who experienced UAP in ED. The control group was comprised of healthy adults with no chronic disease. We performed CA to the patients suspected ACS in the study group, and the Syntax Score was calculated for each patient. The levels of PLR were compared between the study and control group, and PLR levels of the study group were compared with Syntax scores of the former group.

Results: The mean levels of PLR were $122.89 \pm 52.44$ in the UAP group and $104.21 \pm 22.85$ in the control group (p: 0.005 ). The PLR level of 113.98 had a sensitivity of $55.8 \%$, specificity of $66.7 \%$ and was negatively correlated with SXscore ( $r=-0.325 ; p: 0.004)$.

Conclusion: PLR levels significantly increase in patients presenting with UAP. PLR may be considered a novel marker in predicting the severity of UAP. However, it was found to be ineffective in evaluating coronary vascular damage.

Key words: syntax score; platelet-lymphocyte ratio; unstable angina pectoris

\section{ÖZET}

Amaç: Akut Koroner Sendrom (AKS), ST segment yükselmeli miyokard enfarktüsünden kararsız angina pektorise (UAP) kadar geniș bir klinik durum yelpazesini kapsar. UAP, Acil Servis kliniğinde herhangi bir biyobelirteçle tespit edilemez. Trombosit lenfosit oranı (PLR), kardiyak bozukluklarda așırı trombotik aktiviteyi ve enflamasyonu belirlemek için potansiyel bir ișaret olarak gösterilmiștir. Syntax skoru (SXscore), sadece lezyon șiddetini ve kompleksitesini ölçmekle kalmayan, aynı zamanda AKS'li hastalarda mortalite dahil olmak üzere agır kardiyovasküler sonuçları öngören koroner anjiyografiye dayalı anatomik bir skorlama sistemidir. Bu çalıșmanın amacı, UAP'lı hastalarda trombosit lenfosit oranı ile SXscore karșılaștırılarak bu hastalarda PLR'nin prediktif değerini ortaya koymaktır.

Materyal ve Metot: Çalıșma grubu, acil servise bașvuran UAP tanısı alan hastalar ve acil servise'de UAP tanıs alan yetișkin hastalardan olușturuldu. Kontrol grubu, kronik hastalığı olmayan sağlıklı yetișkinlerden olușmuștur. Çalıșma grubunda AKS șüphesi olan hastalara koroner anjiografi uyguladık ve her hasta için Syntax Skoru hesaplandı. Çalıșma ve kontrol grubu arasında PLR seviyeleri karșılaștırıldı ve çalıșma grubunun PLR seviyeleri ile Syntax skorları karșılaștırıldı.

Bulgular: Ortalama PLR düzeyleri UAP grubunda 122,89 $\pm 52,44$ ve kontrol grubunda 104,21 222,85 idi (p: 0,005). PLR düzeyi 113,98 olduğunda \%55,8 duyarlıı̆̆a, \%66,7 özgülüğe sahip olarak bulundu ve SXscore ile negatif korelasyon gösterdiği görülüldü (r=0,325; $p: 0,004)$.

Sonuç: UAP ile bașvuran hastalarda PLR seviyelerinin önemli ölçüde arttığı görüldü. PLR, UAP'ın ciddiyetinin tahmininde yeni bir belirteç olarak düșünülebilir. Ancak koroner vasküler hasarın değerlendirilmesinde etkisiz olduğu görülmüștür.

Anahtar kelimeler: syntax score; platelet-lymphocyte oranl; unstable angina pektoris

IIletișim/Contact: Ahmet Çăgdaş Acara, Department of Emergency Medicine, Urla State Hospital, İzmir, Turkey • Tel: 05052146480 • E-mail: cagdasacara@gmail.com • Geliș/Received: 07.06.2021 • Kabul/Accepted:01.09.2021

ORCID: Ahmet Çăgdaş Acara, 0000-0001-6708-7946 • Mustafa Bolatkale, 0000-0002-7566-3779 


\section{Introduction}

Acute Coronary Syndrome (ACS) is the primary cause of death in the world ${ }^{1}$. The chest pain covers almost $6.3 \%$ of the Emergency Department (ED) ${ }^{2}$. ACS; covers a wide spectrum of clinical conditions ranging from unstable angina pectoris (UAP) to NonST Elevation Myocardial Infarction (N-STEMI) and ST-Elevation Myocardial Infarction (STEMI). UAP is thought to be an ACS in which there are no detectable cardiac biomarkers of myocardial necrosis such as creatine-kinase MB isozyme, troponin, myoglobin in the circulation ${ }^{3}$.

Missed UAP patients are challenging because of various clinical manifestations ${ }^{4}$. Missed Myocardial Infarction is still one of the most common reasons behind malpractice lawsuits against emergency physicians, almost $20 \%$ of all claims 5 . All chest pain patients $<25 \%$ will have an $\mathrm{ACS}^{6}$. If patients at high risk for ACS could be recognized promptly, it has the potential to reduce mortality, morbidity, and adverse effects of delayed treatment ${ }^{7}$. Therefore, accurate and fast risk stratification is paramount in the acute management of these patients, mainly to identify those patients with immediate risk of complications, as those with an ACS.

The Syntax score (SXscore) is an anatomic scoring system based on coronary angiography (CA) designed to be performed by the cardiologist that not only quantifies lesion severity and complexity but also predicts poor cardiovascular outcomes, including mortality, in patients with $\mathrm{ACS}^{8,9}$. The SXscore can predict mortality and morbidity at early and late follow-up in patients irrespective of disease severity in different clinical situations, including ACS. In the PCI study, Capodanno et al. ${ }^{9}$ reported, Patients were divided into tertiles based on SYNTAX scores: low $(\leq 18)$, intermediate $(>18$ to $27)$, and high (>27). At 1 year, patients in the highest tertile showed a significantly higher mortality $(13.1 \%$ vs. $2.5 \%, \mathrm{P}<0.001)$ and MACE rate $(21.4 \%$ vs. $7.4 \%$, $\mathrm{P}<0.001)$ than patients in the lowest tertile ${ }^{10}$.

Early diagnosis and the initiation of appropriate treatment within 24 hours are essential to reduce UAP-related mortality and morbidity ${ }^{11}$. Despite the investigated use of various diagnostic, prognostic and predictive factors, there is currently no biomarker, such as troponin, etc., in patients with UAP. There is still a need for a sensitive, specific, simple, and predictive marker in patients with UAP to reduce mortality and provide a good outcome with cost-effective treatments.
The platelet-lymphocyte ratio (PLR) has been claimed to have the potential as a marker to help identify thrombotic activity and inflammation in cardiac diseases ${ }^{12}$. Inflammatory mediators and endothelial dysfunction play a fundamental role in the pathophysiology of ACS and widespread coronary inflammation found during UAP ${ }^{13}$. It has recently been observed that there is a close relation between cardiovascular mortality and the number of platelets or their ability to aggregate. Platelets play a key role in the pathophysiology of ACS. Compounded with fibrin, platelets form a coronary thrombus ${ }^{14}$. The PLR, which is calculated by dividing absolute platelet count by absolute lymphocyte count, is a new indicator of the inflammatory response. However, recent studies have shown that PLR, which is evaluated as a prognostic marker of ACS, may also increase in patients with N-STEMI and STEMI ${ }^{15-17}$.

However, there are no studies in the literature regarding PLR levels in patients with UAP. No studies in the literature have examined PLR levels compared with SXscore in patients with UAP in the ED. The present study aimed to investigate the predictive value of PLR levels compared with SXscore in patients with UAP in the ED.

\section{Methods}

Medipol University Clinical Research Ethics Committee approved this prospective randomized controlled study. The study was conducted in Medipol University Hospital Adult ED and Cardiology Department within 12 months of approval. (20.01.2016/E.1049-30)

\section{Study and Control Groups}

The study group consisted of patients diagnosed with UAP who presented in ED and adult patients who experienced UAP in ED. UAP was defined according to Thygesen $\mathrm{K}$ et al.'s Third universal definition of myocardial infarction ${ }^{3}$. The control group was comprised of healthy adults with no chronic disease. Patients who agreed to participate in the study provided a written informed consent form. All patients in both groups were $\geq 18$ years old. The groups were named 'UAP' and 'Control.' Gender, Age, hemograms, and PLR levels were recorded for both groups. The study group examined the following: Blood Urea Nitrogen (BUN), creatinine, CK-MB, 0. and 3. Hour cTnI and Syntax score. We performed CA to the patients suspected ACS in the 
study group, and the Syntax Score was calculated for each patient. The levels of PLR were compared between the study and control group, and PLR levels of the study group were compared with Syntax scores of the former group. The cardiologist performed coronary angiography cardiologists interpreted degrees of coronary artery stenosis are separated to make the study double-blinded.

\section{Inclusion and Exclusion Criteria}

\section{Inclusion Criteria}

UAP group: Patients presented with suggestive of UAP above the age of 18 without known previous history of CAD were enrolled in the study.

Control group: The control group consists of healthy adults above 18 with no chronic disease.

\section{Exclusion Criteria}

Patients were also excluded if they had a previously known disease to explain the chest pain other than angina and did not agree to participate in the study.

\section{Biochemical Analysis}

All blood samples were taken from the brachial veins. BUN and creatinine were measured with an autoanalyzer (Cobas6000, Roche, Tokyo, Japan). Blood samples for hemograms were collected in $2 \mathrm{ml}$ EDTA tubes and analyzed on an automated hematology analyzer (XT-2000I; Symex, Osaka, Japan). The PLR was calculated as the ratio of platelet count to lymphocyte count. Blood samples were centrifuged within 30 minutes, and $\mathrm{CK}-\mathrm{MB}$, 0th and 3rd hour cardiac troponin-I (cTnI) were determined with AQT90 FLEX analyzer device (Radiometer, Copenhagen, Denmark) by immunoassay method. Cut-off values for $\mathrm{CK}-\mathrm{MB}$ and $\mathrm{cTnI}$ were $7.2 \mu \mathrm{g} / \mathrm{L}$ and $0.023 \mu \mathrm{g} / \mathrm{L}$, respectively.

\section{Coronary Angiography and Syntax Score}

The cardiologist performed coronary angiography through right femoral catheterization on patients with exertional dyspnea symptoms, chest pain, and without ST-segment and T wave changes (ECG). Blinded experienced interventional cardiologists interpreted degrees of coronary artery stenosis. A syntax scoring system was used to assess angiographic vessel-specific disease severity ${ }^{18}$.

\section{Statistical Analysis}

Statistical analyses were made using commercial statistical software (SPSS Ver. 23.0, IBM Inc., Chicago, IL, USA). Variables were stated as mean and standard deviation. Frequencies were compared with the Chi-square and Fisher's exact tests. Spearman's correlation tests were applied for correlation analyses. Simple correlation analyses were performed to investigate the association of serum PLR levels with SX scores. To determine a cut-off value of PLR level for UAP, receiver operating characteristic (ROC) analysis was performed in sensitivity and specificity calculations. A value of $\mathrm{p}<.05$ was considered statistically significant.

\section{Results}

The study included 77 patients admitted with UAP and 75 control subjects. The mean age was $64.23 \pm 11.02$ years in the study group and $65.36 \pm 10.35$ years in the control group $(\mathrm{p}=0.51)$. The study group comprised 28 (36\%) females and $49(64 \%)$ males and the control group, 28 (37\%) females and 47 (63\%) males $(p=.90)$. In the UAP group, all troponin and CK$\mathrm{MB}$ values were negative. The mean levels of platelet were $241.30 \pm 53.6810^{3} / \mu \mathrm{L}$ and lymphocyte were $2.22 \pm 0.8110^{3} / \mu \mathrm{L}$ in the study group. The mean levels of platelet were $220.44 \pm 40.1310^{3} / \mu \mathrm{L}$, and lymphocyte was $2.18 \pm 0.4810^{3} / \mu \mathrm{L}$ in the control group. The mean levels of PLR of the UAP group (122.89 \pm 52.44$)$ were higher than those of the control group $(104.21 \pm 22.85)$ (Fig. 1, p: 0.005). The area under the ROC curve for the PLR level was 0.597 ( $95 \%$ confidence interval [CI], 0.503-0.690), the PLR level had a sensitivity of $55.8 \%$ and specificity of $66.7 \%$ at 113.98 (Fig. 2). PLR levels were found negatively correlated with SXscore in the study (r=-0.325; p: 0.004) (Fig. 3).

\section{Discussion}

Several factors in cardiac diseases that could lead to predicting in previous studies have been analyzed. However, no studies in the literature have examined PLR levels compared with SXscore to predict the severity of coronary pathology in patients with UAP in the ED.

Most commonly caused by atherosclerosis, ACS is the leading cause of death worldwide. Atherosclerosis is a systemic, lipid-driven immune inflammatory disease ${ }^{14}$. ACS is an inflammatory disease, and serum levels of inflammatory markers, such as interleukin (IL)-6, IL-18, and C-reactive protein, evaluate patients with 


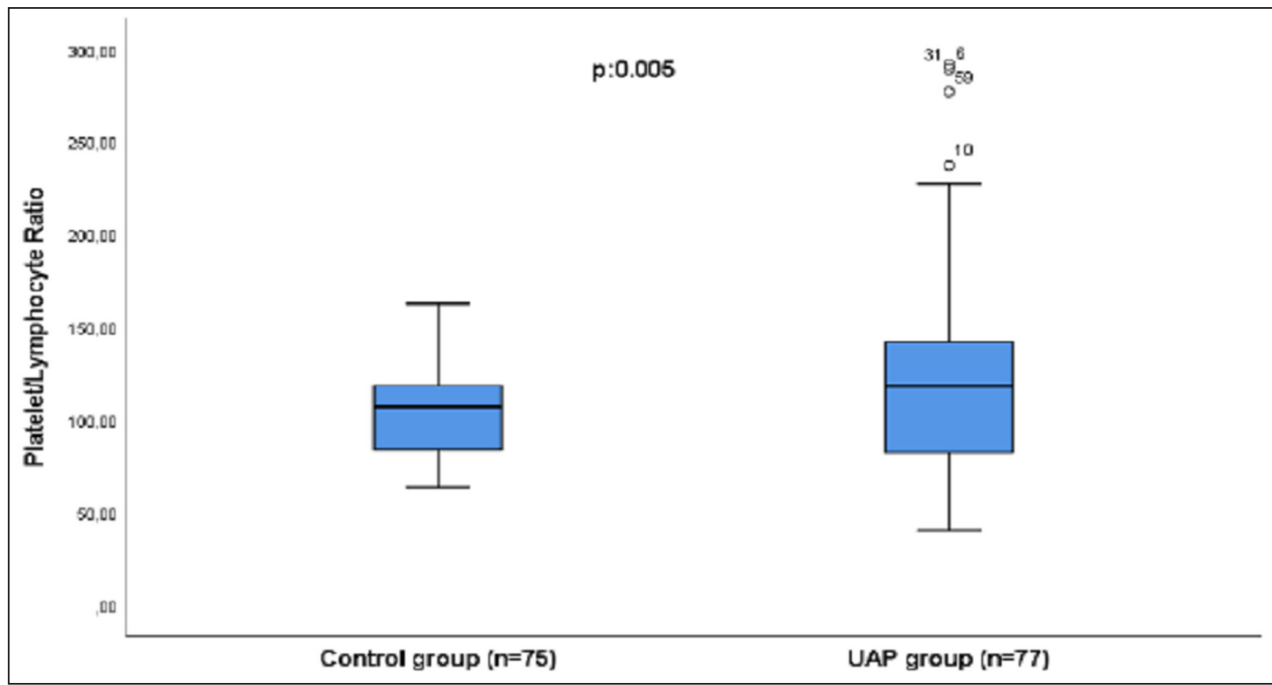

Figure 1. Comparison of PLRs between groups.

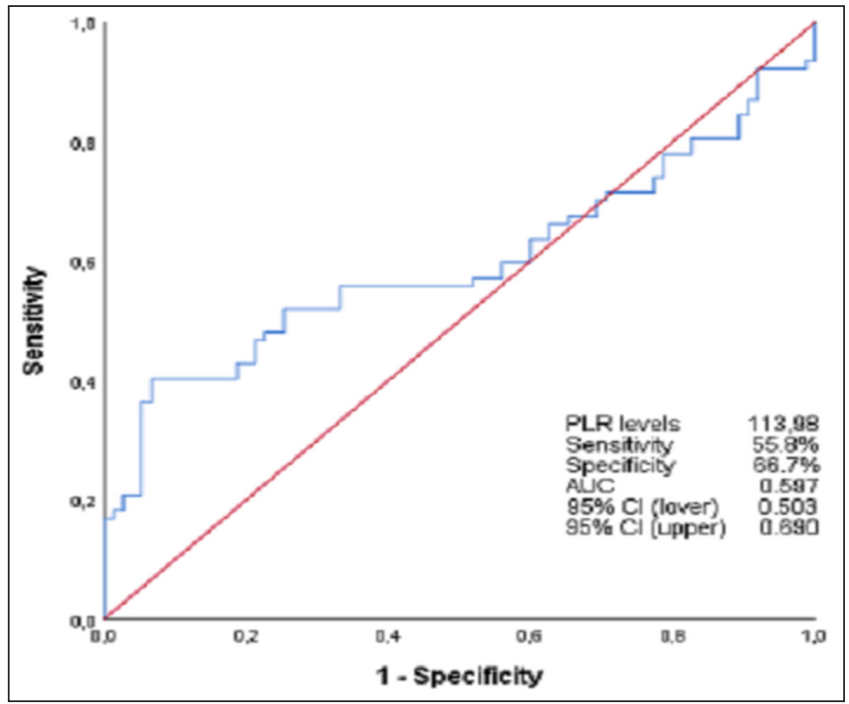

Figure 2. Receiver-operating characteristic analysis of PLR levels for each group (AUC, area under the curve).

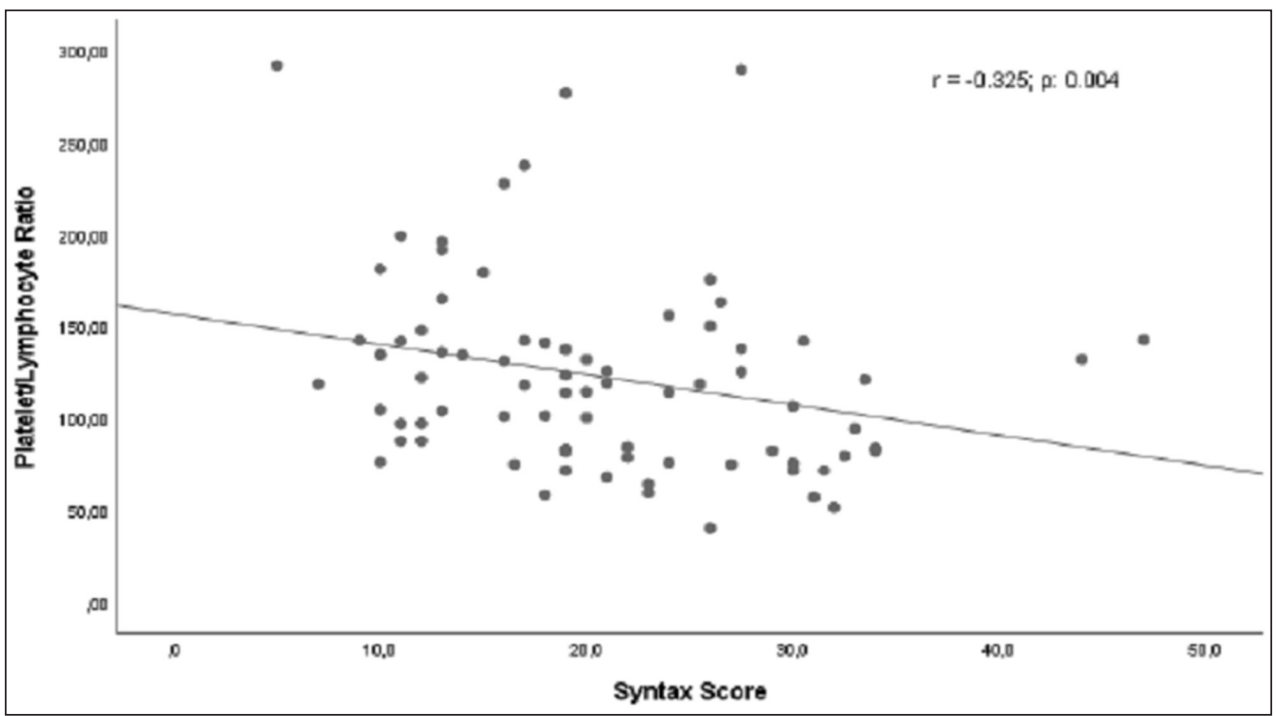

Figure 3. Correlation between PLR and Syntax score. 
$\mathrm{CAD}^{19}$. The inflammation leading to ACS encourages research into the clinical usage of new inflammatory biomarkers. (17). Eight to 10 million individuals are evaluated annually in the EDs in the United States (US) for possible acute $\mathrm{MI}^{20}$. Many of these individuals are assessed with serial cardiac markers and held in observation units for stress testing or cardiac imaging, which is time-consuming and costly. In patients with UAP, the troponin values and repeats are negative, and no detectable blood test is available in the diagnosis of $\mathrm{UAP}$ in the $\mathrm{ED}^{21}$.

Predicting coronary anatomy as early as possible will provide precious information about the major adverse cardiac events (MACE) and risk of cardiac death. The inflammatory processes play a key role in the development of atherosclerosis, destabilization of atherosclerotic plaques, and formation of clots on the plaque surface $^{22}$. Increased platelet activity is closely associated with atherosclerosis and thromboembolic states; ACS increases inflammation in the atherosclerotic plaques within months ${ }^{23}$. It has been suggested that the PLR is a new indicator showing chronic inflammation. In particular, the PLR has been introduced as a potential marker to determine excess thrombotic activity and inflammation in cardiac disorders ${ }^{24}$.

A previous study showed the relationship between PLR and coronary collateral development in patients with stable angina pectoris and chronic total occlusion ${ }^{25}$. In another study, the SXscore is an independent predictor of the 1-year rates of death, cardiac death, MI, and target vessel revascularization in patients with N-STEMI who undergo $\mathrm{PCI}^{26}$, and high preprocedural PLR levels were found to be significant and independent predictors of no-reflow in patients with STEMI ${ }^{27}$. In addition, Kurtul et al. reported; the correlation of PLR with SXscore in patients with ACS, including NSTEMI and STEMI. There was a positive correlation between PLR levels and SXscore in patients with $\mathrm{ACS}^{28}$. However, there are no studies in the literature regarding PLR levels in patients with UAP. No studies in the literature have examined PLR levels compared with SXscore in patients with UAP in the ED. In the present study, although there is a significant increase in serum PLR levels in patients with UAP compared to healthy control subjects, PLR levels were negatively correlated to SXscore in patients with UAP, and PLR levels have a high negative link between SXscores in patients with UAP.

This early and simple prediction by a PLR of inflammation is important. It may improve our ability to risk stratify UAP patients and guide therapeutic decisions and preserve the patients from MACE and risk of sudden cardiac death. The study results have shown that PLR is sufficient to expose high values with poorly battered coronary arteries and has a high negative link between SXscores.

This study showed a significant increase in serum PLR levels in patients with UAP compared to healthy control subjects; recent research has already put this assumption forward ${ }^{29}$. What is novel about this study is that the Syntax score, most widely used to predict coronary artery lesion with CA, was negatively correlated to serum PLR levels in patients with UAP. The previous finding can be explained by the fact that the endothelial nitric oxide levels of coronary arteries in the UAP and the coronary anatomy could not be hardly damaged as can be found in non-ST elevation myocardial infarction and ST-elevation myocardial infarction ${ }^{30}$.

\section{Conclusion}

There is currently no biomarker, such as troponin, etc., to diagnose and predict coronary pathology's severity in patients with UAP in the ED. The PLR may be an important, simple, and cost-effective tool predicting the severity but not the complexity of coronary atherosclerosis in patients with UAP. Thus, the PLR levels can be used for risk stratification in patients with UAP.

\section{Study Limitations}

PLR may be affected by several pathological variables. However, it was not possible in this study to control all the variables that could influence PLR levels. The contact time to the hospital was accepted as the initial hour for this study. The period that started after collecting the first blood samples was not standardized in every patient, and the number of subjects included in the study was limited. And also, patients with UAP were reluctant to undergo coronary angiography procedures; this also kept our list short.

\section{Conflict of Interests}

The author(s) declare no potential conflict of interest regarding this article's research, authorship, and publication.

\section{Funding}

The author(s) received no financial support for this article's research, authorship, and publication. 


\section{References}

1. Finegold JA, Asaria P, Francis DP. Mortality from ischemic heart disease by country, region, and age: statistics from world health organization and united nations. Int J Cardiol 2013;168:934-45.

2. Poldervaart JM, Langedijk M, Backus BE. Comparison of the GRACE, HEART and TIMI scores predict major adverse cardiac events in chest pain patients at the emergency department. Int J Cardiol 2017;15:656-61.

3. Thygesen K, Alpert JS, Jaffe AS, Simoons ML, Chaitman BR, White HD, et al. Third universal definition of myocardial infarction. Eur Heart J 2012;33:2551-67.

4. Leite L, Baptista R, Leitão J, Cochicho J, Breda F, Elvas L, et al. Chest pain in the emergency department: risk stratification with Manchester triage system and HEART score. BMC Cardiovasc Disord 2015;15:48-54.

5. Mehta RH, Eagle KA. Missed diagnoses of acute coronary syndromes in the emergency room-continuing challenges. $\mathrm{N}$ Engl J Med 2000;342:1207-10.

6. Amsterdam EA, Kirk JD, Bluemke DA, Diercks D, Farkouh ME, Garvey JL, et al. Testing of low-risk patients presenting to the emergency department with chest pain: a scientific statement from the American Heart Association. Circulation 2010;122:1756-76.

7. Hoffmann U, Truong QA, Schoenfeld DA, Chou ET, Woodard PK, Nagurney JT, et al. For the ROMICAT-II Investigators, Coronary CT angiography versus standard evaluation in acute chest pain. N Engl J Med 2012;4:299-308.

8. Kappetein AP, Dawkins KD, Mohr FW, Morice MC, Mack MJ, Russell ME, et al. Current percutaneous coronary intervention and coronary artery bypass grafting practices for three-vessel and left main coronary artery disease. Insights from the syntax runin phase. Eur J Cardiothorac Surg 2006;29:486-91.

9. Capodanno D, Di Salvo ME, Cincotta G, Miano M, Tamburino C, Tamburino C. Usefulness of the Syntax score for predicting clinical outcome after percutaneous coronary intervention of unprotected left main coronary artery disease. Circulation Cardiovasc Intv 2009;2:302-8.

10. Capodanno D. Syntax score: reaching optimal revascularisation for complex coronary artery disease. ESC Council for Cardiology Practice 2009;8: N5.

11. Amsterdam EA, Wenger NK, Brindis RG, Casey DE Jr, Ganiats TG, Holmes DR Jr, et al 2014 AHA/ACC Guideline for the Management of Patients With Non-ST-Elevation Acute Coronary Syndromes. J Am Coll Cardiol 2014;64: e139-e228.

12. Toprak C, Tabakci MM, Simsek Z, Arslantas U, Durmus HI, Ocal L, et al. Platelet/lymphocyte ratio was associated with impaired myocardial perfusion and both in-hospital and longterm adverse outcome in patients with ST-segment elevation acute myocardial infarction undergoing primary coronary intervention. Postepy Kardiol Interwencyjnej 2015;11:288-97.

13. Croce K, Libby P. Intertwining of thrombosis and inflammation in atherosclerosis. Curr Opin Hematol 2007;14:55-61.

14. Falk E, Nakano M, Bentzon JF, Finn AV, Virmani R. Update on acute coronary syndromes: the pathologists' view. Eur Heart J 2013;34:719-28.

15. Azab B, Shah N, Akerman M, McGinn Jr JT. Value of platelet/ lymphocyte ratio as a predictor of all-cause mortality after nonSTelevation myocardial infarction. J Thromb Thrombolysis 2012;34:326-34.
16. Sun XP, Li J, Zhu WW, Li DB, Chen H, Li HW, et al. Impact of platelet-tolymphocyte ratio on clinical outcomes in patients with STsegment elevation myocardial infarction. Angiology 2017;68:346-53.

17. Jan Budzianowski, Konrad Pieszko, Paweł Burchardt, Janusz Rzeźniczak, Jarosław Hiczkiewicz. The Role of Hematological Indices in Patients with Acute Coronary Syndrome. Dis Markers 2017;2017:3041565.

18. Poldervaart JM, Langedijk M, Backus BE. Comparison of the GRACE, HEART and TIMI score to predict major adverse cardiac events in chest pain patients at the emergency department. Int J Cardiol 2017;15:656-61.

19. Ataoğlu HE, Yilmaz F, Uzunhasan I, Cetin F, Temiz L, Döventaş YE, et al. Procalcitonin: a novel cardiac marker with prognostic value in acute coronary syndrome. J Int Med Res 2010;38:52-61.

20. McCord J, Cabrera R, Lindahl B, Giannitsis E, Evans K, Nowak $\mathrm{R}$, et al. Prognostic Utility of a Modified HEART Score in Chest Pain Patients in the Emergency Department. Circ Cardiovasc Qual Outcomes 2017;10: pii: e003101.

21. Birim O, van Gameren M, Bogers AJ, Serruys PW, Mohr FW, Kappetein AP. vasculature predicts outcome of surgery for left main disease. Ann Thorac Surg 2009;87:1097-104.

22. Balta S, Celik T, Mikhailidis DP, Ozturk C, Demirkol S, Aparci $\mathrm{M}$, et al. The relation between atherosclerosis and the neutrophillymphocyte ratio. Clin Appl Thromb Hemost 2016;22:405-11.

23. Dutta P, Courties G, Wei Y, Leuschner F, Gorbatov R, Robbins $\mathrm{C}$, et al. Myocardial infarction accelerates atherosclerosis. Nature 2012;487:325-9.

24. Gürsoy OM, Karakoyun S, Kalçık M, Gökdeniz T, Yesin M, Gündüz S, et al. Usefulness of novel hematologic inflammatory parameters to predict prosthetic mitral valve. Am J Cardiol 2014;113:860-4.

25. Açar G, Kalkan ME, Avci A, Alizade E, Tabakci MM, Toprak C, et al. The relation of platelet-lymphocyte ratio and coronary collateral circulation in patients with stable angina pectoris and chronic total occlusion. Clin Appl Thromb Hemost 2015;21:462-8.

26. Palmerini T, Genereux P, Caixeta A, Cristea E, Lansky A, Mehran $\mathrm{R}$, et al. Prognostic value of the SYNTAX score in patients with acute coronary syndromes undergoing percutaneous coronary intervention: analysis from the ACUITY (Acute Catheterization and Urgent Intervention Triage Strategy) trial. J Am Coll Cardiol 2011;57:2389-97.

27. Kurtul A, Yarlioglues M, Murat SN, Ergun G, Duran M, Kasapkara HA, et al. Usefulness of the platelet-tolymphocyte ratio in predicting angiographic reflow after primary percutaneous coronary intervention in patients with acute ST-segment elevation myocardial infarction. Am J Cardiol 2014;114:342-7.

28. Kurtul A, Murat SN, Yarlioglues M, Duran M, Ergun G, Acikgoz SK, et al. Association of Platelet-to-Lymphocyte Ratio With Severity and Complexity of Coronary Artery Disease in Patients With Acute Coronary Syndromes. Am J Cardiol 2014;114:972-8.

29. Bolatkale M, Acara Ahmet Ç. A Novel Index for Prompt Prediction of Severity in Patients with Unstable Angina Pectoris. Emergency Medicine International Volume 2020, Article ID 7651610, 7 pages. https://doi.org/10.1155/2020/7651610

30. Acara Ahmet Ç, Bolatkale M. Endothelial Nitric Oxide Level as a Predictor of Coronary Complexity in Patients With Unstable Angina Pectoris. Am J Med Sci 2019;357(6):453-460. 